\title{
Preliminary Studies on the Content of Phytochemical Compounds On Skin of Salak Fruit (Salaccazalacca)
}

\section{Rety Setyawaty $^{1}$, Ruli Aptuning $B^{2}$, Dewanto ${ }^{3}$}

${ }^{1}$ FakultasFarmasi, Pharmacy Academy of Kusuma Husada, Purwokerto, Indonesia

\section{ARTICLE}

HISTORY

\section{Manuscript}

subbmision :

Agust $16^{\text {th }} 2019$

Manuscript

acceptance for

review : Agust $4^{\text {th }}$

2020

Approval for

publication :

September $30^{\text {th }}$

2020

\section{Keywords :}

Terpene

alcohol,Skin of

salak fruit,

Maceration
A B S T R A C T

Salak (Salaccazalacca) is a native plant of Indonesia. Some Indonesians use zalacca as a traditional medicine. This plant belongs to the Palmae family. The purpose of this study is to reveal the structure of the active components that are efficacious and increase the economic value and efficacy that exist in the skin of zalacca (Salaccazalacca). The extraction method chosen was the maceration method using $96 \%$ ethanol solvent. A total of $1 \mathrm{~kg}$ of fresh zalacca skin (Salaccazalacca) is dried using the sun-heating method and produces $625 \mathrm{~g}$ of dried zalacca skin. The extraction-maceration process uses 100 grams of 1implicial. Simplisia is soaked and stirred occasionally in $96 \%$ ethanol for 3 days and filtered until a thick extract is obtained. Thick extract obtained was $10.69 \mathrm{~g}$. The percentage of yield obtained was $10.69 \%$. Phytochemical screening carried out is alkaloids, steroids, triterpenoids, saponins, tannins, and flavonoids by using chemical reactions and using thin layer chromatography. The mobile phase used in thin layer chromatography is toluene: ethyl acetate (9.3: 0.7). Determination of the mobile phase is done based on a trial and error approach to obtain a clear line of movement. The stationary phase uses silica gel GF 254.Based on phytochemical analysis, the skin of salak fruit (Salaccazalacca) contains alkaloids, triterpenoids, saponins, tannins, and flavonoids. In addition, based on analysis using thin layer chromatography it produces $\mathrm{Rf} 0.1875$ and is thought to contain terpene alcohol.

* Corresponding author: Rety Setyawaty, Jurusan Farmasi, Fakultas Farmasi, Akademi Farmasi Kusuma Husada, Jalan Karangbenda Raya - Berkoh, 


\section{Introduction}

Salak plants (Salaccazalacca) are native plant of Indonesia. Some Indonesian people use Salak as traditional medicine. Particularly in Indonesia, Salak has been widely used as a product that is useful as traditional medicine such as cholesterol lowering. Some parts used as treatment in Indonesia are flesh of fruit, Salak seeds, and Salakskin. ${ }^{(1)}$

According to Dhyanaputriet $a l^{(2)}$, the results of phytochemical tests showed skin of Salak contains flavonoids and tannins and a little alkaloid. Flavonoids can reduce glucose levels in the blood. Ethanolic extract of zalacca contains secondary metabolites of alkaloids, polyphenolates, flavonoids, tannins, quinones, monoterpenes and sesquiterpenes. The extract of zalacca skin has antioxidant activity with IC50 value of $229.27 \pm$ $6.35(\mu \mathrm{g} / \mathrm{mL})^{(2)}$.

Based on Nuranti'sresearch ${ }^{(3)}$, Salak skin extract can be beneficial for reducing cholesterol levels. This research was conducted by in vitro testing of male Swiss Webster mice induced by a high-fat diet. The results of phytochemical screening on zalacca skin extracts contain alkaloids, polyphenols, flavonoids, quinones, tannins, triterpenoids and steroids ${ }^{(3)}$. Based on these descriptions, the authors are interested in researching the phytochemical of Salak skin fruits.

\section{Methode}

Materials

Vessel for maceration complete with cover and stirrer, analytical scales, ovens, glassware, aluminum foil, mori cloth, waterbath, porcelain cups, test tubes, tube racks, dropper pipettes, filter paper, chamber, silica gel GF 254 $\mathrm{nm}$, UV light $254 \mathrm{~nm}$ and $366 \mathrm{~nm}$.

The materials used in this study were the skin of Salak fruits, 96\% ethanol, dilute ammonia (10\%), Chloroform, $\mathrm{HCl} 2 \mathrm{~N}$, Ether, Sulfuric Acid, aqueous Chloride Acid, $10 \%$ Iron (III) chloride solution, $\mathrm{Mg}$ Powder, Amyl Alcohol, Ethyl Acetate, Vanilin 10\%, Lieberman-Burchard reagents, Mayer reagents and Dragendorffreagents.

\section{Methods \\ Determination}

Determination of the Salaccazalacca plant aims to ensure and ensure that the ingredients used are really Salaccazalacca. Determination of plants is carried out at the Plant Taxonomy Laboratory, Faculty of Biology, University of JenderalSoedirman, Purwokerto.

\section{Sampling}

Salak fruit skin that is used for research comes from old Salak fruits. The weight of fresh skin of Salak fruits are 1 $\mathrm{kg}$.

\section{Drying method}

Salak fruit skin is washed and dried in direct sunlight with a black cloth covered so that the active substances contained are not damaged by direct sunlight. Furthermore, dried Salak fruit skin is blended to form a coarse powder.

\section{Maceration Process}

In this study, Salak skin was extracted using $96 \%$ ethanol solvent. The extract was made using maceration method, which is $100 \mathrm{~g}$ of coarse powder of Salak skin put into a glass beaker and then added $96 \mathrm{ml}$ of ethanol as much as $500 \mathrm{ml}$, covered and allowed to soak for 3 days protected from light (every day stirring for at least 30 minutes). The extract is then filtered using mori cloth so that it is obtained filtrate.

\section{Phytochemical analysis}

\section{- Alkaloid Examination}

A $2 \mathrm{ml}$ extract solution was evaporated on a porcelain cup until it got a residue. The residue dissolved with $5 \mathrm{ml}$ of diluted ammonia (10\%) and added with $2 \mathrm{ml}$ of chloroform and filtered. The filtrate was added with $2 \mathrm{~N}$ $\mathrm{HCl}$ then shaken out to form 2 layers. There were 2 layers, namely $2 \mathrm{~N} \mathrm{HCl}$ layer and Chloroform layer. The layer containing $2 \mathrm{~N} \mathrm{HCl}$ was taken using a $3 \mathrm{ml}$ pipette and then divided into 3 test tubes. The first tube functions as a blank. The second tube is added Dragendroff reagent as much as 3 drops, if orange, yellow to brown precipitate is formed indicating the presence of alkaloids. The third tube was added by Mayer reagent as much as 3 drop, if a white to yellowish sediment was formed indicating the presence of alkaloids. ${ }^{(4)}$

\section{- Steroid and Triterpenoid Examination}

A sample of $2 \mathrm{ml}(\mathrm{w} / \mathrm{v})$ was extracted with ether then evaporated to dryness. Lieberman-Burchard reagent is deposited on the residue. The formation of purple color indicates triterpenoid group content, whereas if green-blue color is formed, it indicates the presence of steroid group compounds. $^{(5)}$

\section{- Saponin Examination}

A sample of $2 \mathrm{ml}$ was dissolved with $10 \mathrm{ml}$ of distilled water in a test tube. After it chilled the filtrate in the test tube is shaken vigorously for about 30 seconds. The reaction will stop or be in a resting phase if the reaction temperature is equal to room temperature. Formation of foam with a height of at least $1 \mathrm{~cm}$ and persistent for 10 minutes and not lost on the addition of 1 drop of dilute hydrochloric acid shows saponins content. ${ }^{(5)}$

\section{- Tanin Examination}

The $2 \mathrm{ml}$ extract solution was reacted with $10 \%$ iron 
(III) chloride solution, if dark blue, black blue or greenish black showed the presence of tannin compounds ${ }^{(4)}$.

\section{- Flavonoid Examination}

Sample $2 \mathrm{ml}$ of sample was added $0.1 \mathrm{mg}$ of $\mathrm{Mg}$ powder, $1 \mathrm{ml}$ of concentrated $\mathrm{HCl}$ and $1 \mathrm{ml}$ of Amyl Alcohol then shaken strongly. The presence of flavonoids is indicated by the presence of red, yellow or orange in the Amyl Alcohol layer. ${ }^{(5)}$

\section{Thin Layer of Chromatography (TLC) analysis}

The extract was bottled 1 time on a $245 \mathrm{~nm}$ GF silica gel plate which had been activated at $100{ }^{\circ} \mathrm{C}$ for 3 minutes, bottling $1.5 \mathrm{~cm}$ from the bottom edge and the eluent distance from the top edge was $0.5 \mathrm{~cm}$. The mobile phase propagation distance is $8 \mathrm{~cm}$ and then the silica gel plate is inserted into the chamber containing the mobile phase, namely toluene : ethyl acetate (9.3:0.7). The saturated mobile phase is used as much as $10 \mathrm{ml}$. Fulfillment of the mobile phase is done by inserting filter paper into the chamber, after the mobile phase propagates to the creeping limit then the mobile phase has been saturated. The plates are removed, dried in the air and then detected by UV light with wavelengths of $254 \mathrm{~nm}$ and $366 \mathrm{~nm} .^{(6)}$

\section{Result and Discussions}

\section{Determination}

The results of the determination state that the plant used is SalaccaZalacca, with the following details:

Family: Arecaceae.

Genus: Salacca

Species: Salaccazalacca (Gaertn.) Voss

\section{Yield}

Salak fruit peel extract yield is not more than $10.73 \%^{(7)}$. The extract yield obtained in this study was $10.69 \%$ or less than $10.73 \%$ due to the possibility of taking too long to evaporate. According to Yuliantiet $a l^{(8)}$ the length of the extraction process was very influential on the extracts produced.

\section{Phytochemical analysis}

\section{- $\quad$ Result of alkaloid}

The results of phytochemical analysis of Salak skin are presented in Table 1. Phytochemical analysis results showed that the Salak skin contains alkaloid compounds ${ }^{(7)}$. In this study, Salak skin positive contains alkaloid compounds due to the formation of yellow precipitate in the Dragendorf reagent test and white precipitate in the Mayer reagent test. This is in line with research conducted by Marlianaet $a l^{(9)}$. Marlianaet $a l^{(9)}$ conducted a study on Phytochemical Screening and Analysis of Thin Layer Chromatography Components Chemistry of Siamese Pumpkin (Sechium edule Jacq. Swartz.) In Ethanol Extract.
Table 1. Result of phytochemical screening analysis

\begin{tabular}{lllc}
\hline $\begin{array}{l}\text { Chemical } \\
\text { content }\end{array}$ & Testing Method & Results & Annotation \\
\hline Alkaloid & $\begin{array}{l}\text { Dragendorff } \\
\text { Mayer }\end{array}$ & $\begin{array}{l}\text { Yellow } \\
\text { White }\end{array}$ & + \\
\hline $\begin{array}{l}\text { Steroid } \\
\text { Triterpenoid }\end{array}$ & $\begin{array}{l}\text { Lieberman- } \\
\text { Burchard }\end{array}$ & Purple & + \\
\hline Saponin & $\begin{array}{l}\text { Aquadest } \\
\text { (shaking) }\end{array}$ & Bubble & + \\
\hline Tanin & $\begin{array}{l}\text { Iron (III) chloride } \\
10 \% \text { solution }\end{array}$ & Sedimentation & + \\
\hline Flavonoid & $\begin{array}{l}\text { Mg powder, HCl } \\
\text { 2N Amyl Amyl } \\
\text { alcohol }\end{array}$ & Yellow & + \\
\hline
\end{tabular}

Positive alkaloid results in the Dragendorff test were characterized by the formation of orange, yellow to brown deposits. The precipitate is potassium alkaloids which are the result of the reaction produced between Dragendorf reagents which bind with alkaloids ${ }^{(10)}$. On the other hand, positive alkaloid results in the Mayer test are characterized by the formation of white to yellowish deposits. It is estimated that these deposits are the result of Mayer reagents that bind with alkaloids through a coordinating bond between $\mathrm{N}$ alkaloid atoms and $\mathrm{Hg}$ Mayer reagents to produce mercury complex compounds that are non polar precipitating white to yellow ${ }^{(11)}$.

The purpose of adding aqueous ammonia (10\%) serves to alkalize and precipitate the alkaloids so that the alkaloids can be obtained in the form of salt or free base. Chloroform is used with the aim of being able to attract alkaloid compounds because alkaloids have good solubility in chloroform ${ }^{(12)}$. The purpose of adding $\mathrm{HCl} 2 \mathrm{~N}$ is to attract alkaloids because alkaloids are alkaline so they are reacted using acidic solvents ${ }^{(10)}$. The results of the alkaloid analysis can be seen in Fig. 1.

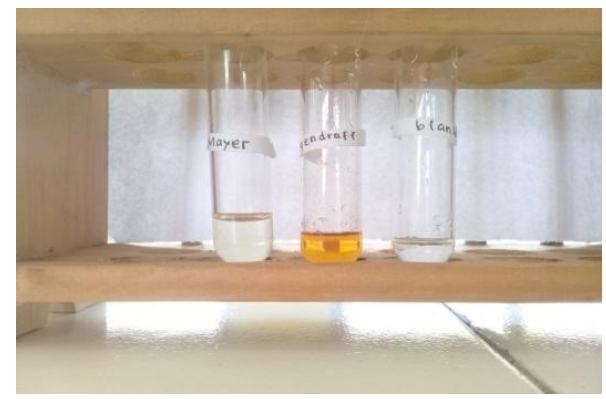

Fig. 1. Result of alkaloid compound analysis

\section{- $\quad$ Result of Steroid and Triterpenoid}

The results of phytochemical analysis showed that the Salak skin contained triterpenoid compounds but did not contain steroid compounds. Negative results on steroid compounds can be caused by lack of sensitivity of the tool, the levels of compounds in the skin of the salak fruit is too 
little or the skin of the salak fruit does not meet the requirements so that the existing compounds become lost or damaged due to enzymatic reactions or hydrolysis. Positive results on triterpenoid compounds can be caused by tool errors or the influence of compounds that have similar properties and identical atomic structures ${ }^{(13)}$. This is in line with research conducted by Simaremare ${ }^{(14)}$. Simaremare $^{(14)}$ conducted a study on phytochemical screening of ethanol extract of itchy leaves (Laportea decumana (Roxb.) Wedd). The results obtained from this study formed red orange or purple for terpenoids and blue for steroids.

The purpose of the search for using ether is to attract chemical compounds in the sample. This is because ether is an excellent solvent for extraction and for various chemical reactions ${ }^{(15)}$. The Lieberman-Burchard reagent is a mixture of acetic anhydride and concentrated $\mathrm{H}_{2} \mathrm{SO}_{4}$. When the compound in the extract is dripped by $\mathrm{H}_{2} \mathrm{SO}_{4}$ through the cup wall, the acetic anhydride will react with the acid so that the $\mathrm{C}$ atoms in the anhydride form a carbocation. The carbocation formed reacts with the $\mathrm{O}$ atom in the $\mathrm{OH}^{-}$ group present in steroid compounds or triterpenoids. This reaction is an esterification reaction, namely the formation of ester compounds by steroid compounds or triterpenoids with acetic anhydride. The reaction process that produces color changes in the test using Lieberman-Burchard reagents $^{(5)}$.

The Lieberman-Burchard reagent is a mixture of acetic anhydride and concentrated $\mathrm{H}_{2} \mathrm{SO}_{4}$. When the compound in the extract is dripped by $\mathrm{H}_{2} \mathrm{SO}_{4}$ through the cup wall, the acetic anhydride will react with the acid so that the $\mathrm{C}$ atoms in the anhydride form a carbocation. The carbocation formed reacts with the $\mathrm{O}$ atom in the $-\mathrm{OH}$ group present in steroid compounds or triterpenoids. This reaction is an esterification reaction, namely the formation of ester compounds by steroid compounds or triterpenoids with acetic anhydride. The reaction process that produces color changes in the test using Lieberman-Burchard reagents ${ }^{(5)}$. The result of steroid and triterpenoid analysis can be seen in Fig. 2.

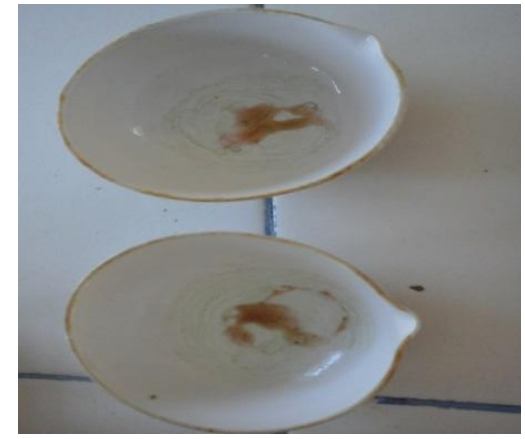

Fig. 2. Result of steroid and triterpenoid analysis

\section{- $\quad$ Result of Saponin}

In this study, the salak fruit skin positively contained saponin compounds due to the formation of foam as high as $1.5 \mathrm{~cm}$ and persistent for 10 minutes. The foam formation in the saponin compound test is caused by a soapy substance present in the salak skin. Saponin test results are shown by the emergence of foam which is a glycoside that has the ability to form froth in water that is hydrolyzed into glucose and other compounds ${ }^{(16)}$. Test results stating simplicia contain saponins can be seen in Fig. 3.

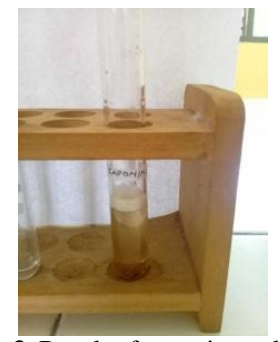

Fig. 3. Result of saponin analysis

This is in line with research conducted by Bintoroet $a l^{(17)}$. Bintoroet $a l^{(17)}$ conducted research on the analysis and identification of saponin compounds from the leaves of bidara (Zhizipusmauritania $L$.) which produced foam after shaking and adding $2 \mathrm{~N}$ hydrochloric acid reagents, the foam formed did not disappear.

\section{- $\quad$ Result of Tannin}

In this research, salak skin contains tannins due to the formation of greenish black. The addition of $\mathrm{FeCl}_{3}$ was used to determine the presence of phenol groups in the sample. The formation of color changes in the extract after the addition of $\mathrm{FeCl}_{3}$ is caused by tannins forming complex compounds with $\mathrm{Fe}^{3+}$ ions. The presence of tannin will precipitate the protein in gelatin. Tannins react with gelatin to form solid copolymers that are insoluble in water ${ }^{(10)}$. The results of tannin analysis can be seen in Fig. 4.

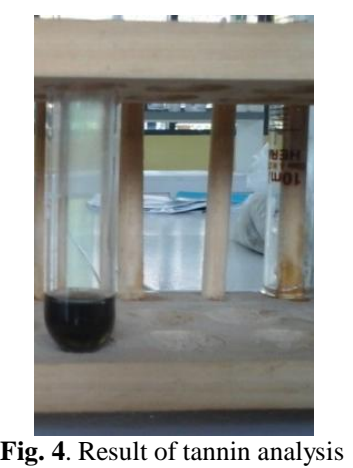

This is in line with research conducted by Indarto ${ }^{(18)}$. Indarto ${ }^{(18)}$ conducted a study on qualitative and quantitative tests of groups of organic compounds from the bark and wood of Artocarpus dadahMiq plants. Indarto ${ }^{(18)}$ obtained tannin test results from bark and wood sample with $\mathrm{FeCl}_{3}$ 
reagent $0.1 \%$ shows a positive test that is the color of the solution to yellowish green for bark and greenish brown for woody stems. This happens because of a reduction reaction. Tannins are a class of polyphenol compounds, able to reduce polyphenols iron (III) becomes iron (II). This is also the way classic for detecting phenol compounds, namely by adding a solution of $1 \%$ iron (III) chloride in water or ethanol to the sample solution giving rise to green, red, purple, blue or black.

\section{- $\quad$ Result of Flavonoid}

In this research, salak fruit skin contains flavonoids due to the formation of yellow deposits. The purpose of adding concentrated $\mathrm{Mg}$ and $\mathrm{HCl}$ powders is to hydrolyze flavonoids to aglycones. Flavonoids will be reduced with $\mathrm{Mg}$ and $\mathrm{HCl}$ can give red, yellow or orange ${ }^{(5)}$. The addition of amyl alcohol aims to attract free flavonoids, so that the colorless Amyl Alcohol becomes discolored from the flavonoids. Flavonoid compounds are polarcompound, so they dissolve in polar amyl alcohol ${ }^{(19)}$. The result of flavonoid analysis can be seen in Fig. 5 .

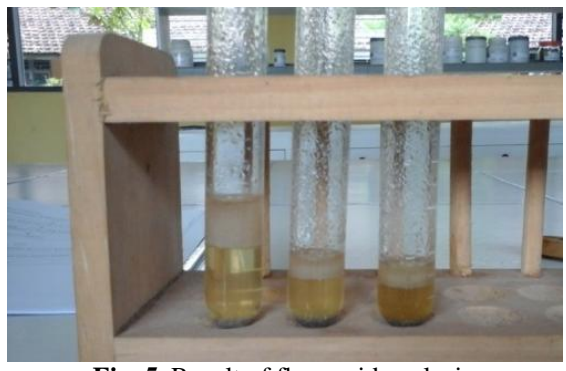

Fig. 5. Result of flavonoid analysis

Thin Layer of Chromatography (TLC) analysis

Thin Layer Chromatography Test (TLC) on extract of Salak skin using UV light $366 \mathrm{~nm}$ and $254 \mathrm{~nm}$ under the mobile phase, namely toluene: ethyl acetate (9.3:0.7) showed a spot stain with Rf 0.1875 . In this study stain spots were seen using UV light $366 \mathrm{~nm}$ and $254 \mathrm{~nm}$. The spot of staining were suspected terpene alcohol.Thin Layer Chromatography (TLC) test results under $254 \mathrm{~nm}$ can be seen in Fig. 6a. Thin Layer Chromatography (TLC) test results under $366 \mathrm{~nm}$ can be seen in Fig. $\mathbf{6 b}$.



Fig. 6a. Result of TLC analysis under $254 \mathrm{~nm}$

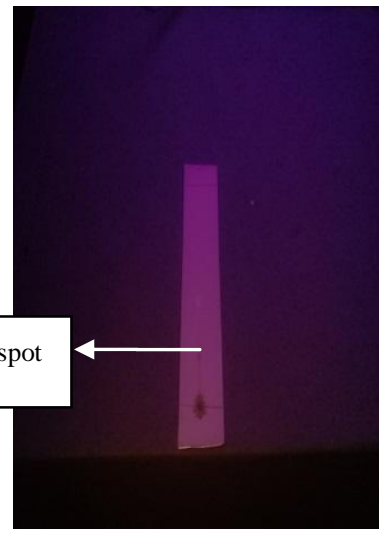

Fig. 6b. Result of TLC analysis under $366 \mathrm{~nm}$

\section{References}

1. Joshua S. and Rano K. Keanekaragaman Aktivitas Farmakologi Tanaman Salak (Salacca Zalacca). Farmaka, Suplemen. 2018 August; 16(1).

2. Dhayanaputri IGAS, Karta IW, and Luh Ade WK. Analisis Kandungan Gizi Ekstrak Kulit Salak Produksi Kelompok Tani Abian Salak Desa Sibetan Sebagai Upaya Pengembangan Potensi Produk Pangan Lokal. Meditory. 2016 December; 4(2).

3. Nuranti NN, Fitrianingsih SP dan Lestari F. Uji Aktivitas Anti Hiperkolesterolmia Ekstrak Etanol Kulit Buah Salak (Salacca Zalacca (Gaertner.) Voss) terhadap Mencit Swiss Webster Jantan yang diinduksi Diet Tinggi Lemak. Prosiding Penelitian SPeSIA UNISBA. 2015 August.

4. Jones WP and Kinghorn AD. Extraction of Plant Secondary Metabolites. In: Sarker S D, Latif Z. and Gray AI, eds. Natural Products Isolation. $2^{\text {nd }}$ Ed. Humana Press. New Jersey. 2006.

5. Latif RH. Identifikasi Kandungan Kimia Pada Buah Labu Siam (Sechiumedule (jacq.) Sw.) [KaryaTulis Ilmiah]. Purwokerto: Akademi Farmasi Kusuma Husada. 2017.

6. Setyaningrum $\mathrm{M}$ and Edy Cahyono. Pemisahan Stronelal menggunakan Kromatografi Kolom dengan Fasa Diam Siklodekstrin Terasetilasi. Indonesian Journal of Chemical Science. 2016 August; 5(2).

7. Sahputra FM. Potensi ekstrak kulit dan daging buah salak sebagai anti diabetes [skripsi]. Bogor: Fakultas Matematika dan Ilmu Pengetahuan Alam, Institut Pertanian Bogor. 2008.

8. Yulianti D, Susilo B, and RiniYulianingsih. Influence of Extraction Time and Ethanol Solvent Concentration to Physical-Chemical Properties Stevia leaf Extract (Stevia RebaudianaBertoni M.) 
using Microwave Assisted Extraction Methods. Jurnal Bioproses Komoditas Tropis. 2014 June; 2(1).

9. Marliana SD, Suryanti V, and Suyono. The phytochemical screenings and thin layer chromatography analysis of chemical compounds in ethanol extract of labusiam fruit (Sechium edule Jacq. Swartz.). Biofarmasi. 2005 January; 3(1).

10. Harborne J. Metode Fitokimia: Penuntun Cara Modern Menganalisis. Tumbuhan. Bandung: ITB. 1996.

11. Isnania F and Wehantouw F. Aktivitas Diuretik dan Skrining Fitokimia Ekstrak Etanol Biji Pepaya (Carica papaya L) Pada Tikus Putih Jantan Galur Wistar (Rattus norvegicus). Jurnal Ilmiah Farmasi. 2014 August; 3(3).

12. Ramdani D, Chaudhry AS, and Chris JS. Alkaloid and polyphenol analysis by HPLC in green and black tea powders and their potential use as additives in ruminant diets. AIP Conference Proceedings 1927. 2018 February; 030008-1 - 030008-6.

13. Wirawan D, Agustinawati M, R Nuning, R, A Nur L, Setiawan IA, M Qibthiyah M, S Valentina F, Prabawasari Y, Nurrosyidah S, Damayanti YD, Imaniar H, Sutatik Putri TZ, Amardhika ME, and Widyaning DA. Laporan Praktikum Fitokimia: Skrining Fitokimia. Laboratorium Biologi, Universitas Jember. 2016.

14. Simaremare ES. Skrining Fitokimia Ekstrak Etanol Daun Gatal (Laportea decumana (Roxb.) Wedd). Pharmacy. 2014 July; 11(01).

15. Sunarya Y and A Setiabudi. Mudah dan Aktif Belajar Kimia 3. Jakarta: Departemen Pendidikan Nasional. 2009; 298.

16. Rusdi. Tetumbuhan Sebagai Bahan Obat. Padang: Pusat Penelitian Universitas Andalas. 1990.

17. Bintoro A, Ibrahum AM, and Boima Situmeang. Analysis and Identification of Saponin Compound from Bidara Leaves (Zhizipusmauritania L.). Jurnal ITEKIMA. 2017 August; 2(1).

18. Indarto. Uji Kulaitatif dan Kuantitatif Golongan Senyawa Organik dari Kulit dan Kayu Batang Tumbuhan Artocarpus dadah Miq. Jurnal Ilmiah Pendidikan Fisika Al-Biru Ni. 2015; 4(1).

19. Anderson R. Isolasi dan identifikasi senyawa flavonoid pada daun kejibeling [KaryaIlmiah]. Bandung: UNISBA; 2018. 